University of Massachusetts Amherst ScholarWorks@UMass Amherst

2010

\title{
Slave Mothers and White Fathers: Defining Family and Status in Late Colonial Cuba
}

Karen Y.Morrison

University of Massachusetts - Amherst, kymorris@afroam.umass.edu

Follow this and additional works at: https://scholarworks.umass.edu/afroam_faculty_pubs

\section{Recommended Citation}

Morrison, Karen Y., "Slave Mothers and White Fathers: Defining Family and Status in Late Colonial Cuba" (2010). Slavery \& Abolition. 30 .

$10.1080 / 01440390903481647$

This Article is brought to you for free and open access by the Afro-American Studies at ScholarWorks@UMass Amherst. It has been accepted for inclusion in Afro-American Studies Faculty Publication Series by an authorized administrator of ScholarWorks@UMass Amherst. For more information, please contact scholarworks@library.umass.edu. 


\title{
Slave Mothers and White Fathers: Defining Family and Status in Late Colonial Cuba
}

\author{
Karen Y. Morrison
}

This paper outlines the mechanisms used to position the offspring of slave women and white men at various points within late nineteenth-century Cuba's racial hierarchy. The reproductive choices available to these parents allowed for small, but significant, transformations to the existing patterns of race and challenged the social separation that typically under girded African slavery in the Americas. As white men mated with black and mulatta women, they were critical agents in the initial determination of their children's status-as slave, free, mulatto, or even white. This definitional flexibility fostered an unintended corruption of the very meaning of whiteness. Similarly, through mating with white men, enslaved women exercised a degree of procreative choice, despite their subjugated condition. In acknowledging the range of rape, concubinage, and marriage exercised between slave women and white men, this paper highlights the important links between reproductive practices and the social construction of race.

Many white gentlemen, of considerable respectability among the Spaniards, are seen to walk the streets with their sweet black wenches by their sides, perhaps each leading a lusty copper-colored infant sans culotte by the hand.

A British North American soldier in Havana, 1762. ${ }^{1}$

In 1875, a white Galician shop owner, Don Francisco Franco, wrote to the Bishop of Havana in an effort to clarify his children's paternity. The documents associated with such a petition normally would have been commonplace and uncomplicated, among the many initiated by late nineteenth-century Cuban men for the paternal recognition of children born outside of wedlock. However, the intrigue hidden in Don Francisco's much more complex case reveals interesting elements of Cuba's contemporary racial dynamics. In the petition's first document, Don Francisco not only admitted that his eight children had been born outside of wedlock; he also confessed the fabricated contents of the children's baptismal records. He claimed that to protect the children 
from future shame, in six of their baptisms, 'por capricho' (on a whim) he had named a fictitious, married Spanish couple as the parents. Of the remaining two children, one was an infant who had not yet been baptised. The other - his oldest child - had been baptised 15 years earlier, in 1860, as a white exposita, or orphan protected by the Spanish Crown. Within a year of her birth, that child was returned to Don Francisco, who assumed the role of a legal guardian, but who at that time did not acknowledge himself as her father. ${ }^{2}$

The attempt to baptise the youngest child under circumstances similar to the other six led Don Francisco's new parish priest to question the existence of the named parents. After launching a local investigation, the priest discovered, 'It is shameful public knowledge that the man [Don Francisco] has lived in scandalous concubinage with a mulatta with whom he has had and continues to have children.' ${ }^{3}$ That the unnamed mother was also a slave only made Don Francisco's deception more comprehensible. Not only had he wanted to spare the children the stigma of illegitimacy but perhaps also from association with slavery and mixed-race identity. The priest's exposure of the family's true nature prompted Don Francisco to correct the official records and claim his children legally. By then the paternal relationship between Don Francisco and the offspring of a slave had been shifted out of its status as a public secret (tacitly acknowledged by the community) to become a problem for the social order that Cuban colonial authorities needed to address. Put simply, Don Francisco had disturbed the society's racial codes by failing to accept the standard designations of illegitimacy, mulatto identity, and possible enslavement for his children. In fact, his successful provision of white legal identities to his racially mixed progeny on seven previous occasions implies a prioritisation of family bonds and familial advancement above supporting the norms of racial attribution. He had willingly undermined accepted racial categories in the effort to improve his children's social standing.

While Don Francisco's case could stand alone as a fascinating historical anecdote, coupling it with similar cases generates a broader, more dynamic image of Cuban interracial relations under slavery and demonstrates their value in undermining the racial basis of Cuban slavery. ${ }^{4}$ In doing so, this paper also opens important historiographic comparisons with other slave-holding regions of the Americas. Don Francisco's petition was but one of 45 similar recognitions of children born to white fathers and slave mothers brought before the Bishop of Havana between 1861 and $1893 .^{5}$ White men of distinct occupations and national origins, who lived in various Cuban settings ranging from urban Havana to small rural villages, submitted these claims. ${ }^{6}$ Collectively, these diverse petitions highlight unexpected ruptures in slavery's social strictures, breaches in racial etiquette that refer only in part to the gradual abolition process that had marked Cuban society since 1820. As of that year, Cuban abolition progressed along five key stages: (1) the 1820 criminalisation of the African slave trade; (2) the 1868 liberation of the slaves of Cuban independence patriots; (3) the 1870 Moret Law that freed elderly slaves, children born to slave mothers after 17 September 1868, slaves owned by the Spanish government, and African emancipados who had been illegally transported to Cuba after 1820; (4) the 1880 patronato law creating 
an eight-year apprenticeship period to facilitate the transitions to wage labour; and (5) the 1886 final emancipation. ${ }^{7}$ The fathers who eventually claimed their mixed-race children were similar to other mid-nineteenth-century Cubans who, regardless of social status, initially did not foresee their country completely devoid of slave labour. Yet they were participants in and witnesses to its decline. By 7 October 1886, official emancipation was complete, and formerly enslaved Cubans continued to integrate themselves into the life of the emergent nation. It is in this transition that the sexual relationships between white men and enslaved women common to all slave societies in the Americas made unique contributions to the specifics of racial meaning in Cuba.

What follows analyses these liaisons as a subset of the racialised reproductive behaviours prevalent in American plantation societies. The collective review of these Cuban unions outlines the tensions between personal aspirations and larger societal structures, such as race, family, and community. These paternity petitions transcend the often separate histories of whites and of slaves and identify subtle aspects of their interaction, moments of family formation. ${ }^{8}$ The white men seen here legally acknowledged children reproduced through enslaved black and mulatta women and provided them with their initial social identities, as either slave, free mulatto, or even white. A review of these experiences exposes not only the racial attitudes of whites and enslaved people. A dissonance between the public and private manifestations of race is revealed in the process. This study thus exposes three previously hidden and closely interwoven levels of racial transformation in late colonial Cuba: (1) an interracial intimacy that decreased the social distance between Cuba's whites and people of colour and at times increased the scope of self-determination for women of colour; (2) the practice of a familial form of white power that did not rest exclusively on the use of violence toward people of colour; and (3) the intentional corruption of notions of white racial purity, often by whites themselves. Thus, even though these 45 cases may not be representative, they expand our understanding both of slavery's reproductive practices and of the transformative actions that repeatedly appeared at its fringes, as blacks and whites together gave birth to alternative structures of race and family.

\section{Documenting interracial families under slavery}

The general interpretation of sexual contacts between white men and enslaved women has developed around a few normative themes. Rape and seduction occupy distinct and unresolved extremes in the historical depictions of these encounters. US African-American historiography has tended to highlight the real violence and mistreatment endured by enslaved black women. This portrayal reveals cruel, lustful white masters and overseers who subjected their bondwomen to the dual burdens of chattel labour and sexual abuse. In such situations, female slaves struggled to maintain their dignity but were unable to withstand the brutal onslaught. ${ }^{9}$ Family dissolution and personal shame were the results. This historiography has stressed that rarely did the children born to these experiences benefit from any association with a white father. Rather, social conventions and the 'one drop rule' of black hypodescent 
ensured that they generally suffered the same denial of their humanity as other enslaved people. ${ }^{10}$

Latin American engagement with slavery's interracial sexual contact de-emphasised violence, especially for Brazil, whose experience with slavery most directly compares to Cuba's. There, first-generation slave studies often framed slave reproduction in terms of promiscuity. This notion was also coupled with a belief in slaves' rejection of and inability to form lasting families. ${ }^{11}$ A precedent for such interpretation was set by Gilberto Freyre, who depicted black women as active sexual initiators, or Jezebellike seductresses, who hoped to improve their own condition or that of their offspring through even the most fleeting liaisons with white men. ${ }^{12}$ The outcome of such actions has frequently been described as variation on 'the mulatto escape hatch' theme, with an emphasis on the distinct social status achieved by mixed-race children. ${ }^{13}$ Although this image of mulatto upward mobility has received considerable challenge in other areas of Brazilian studies, it persists in the analysis of slave reproduction. ${ }^{14}$

Despite the contrast in the US and Brazilian treatments of slavery's contribution to the growth of mixed-race populations, both historiographies offer an oversimplification that belies the more complex historical reality. Both frequently portray mulattos as alienated individuals - either alone in the world or united almost exclusively among themselves into an intermediate social category - with few profound connections to their separate white and enslaved ancestries. ${ }^{15}$ This image has created in both US and Brazilian approaches to interracial sexual relations under slavery a disregard of the concept of 'family'. Indeed, many reviewers emphasise the more short-lived sexual experiences, without sustained attention to the interactions between white men and slave women that at times generated lasting bonds of affection and kin-like affinity. As a result, many of the reproductive and familial aspects of these experiences are left to linger in historiographic oblivion; that is, such unions are not given sociological importance. Rather, they are regarded individually as anecdotal and unrepresentative, with little value as historical agents, except as generators of a growing mixed-race population. ${ }^{16}$ For nineteenth-century Cuba, however, the sheer number of lasting, intimate encounters between white men and slave women precludes their dismissal as anecdotal, even though many remain undocumented. Indeed, the significant size of the mulatto population is only one indication of the extent to which even the most trivial of these sexual encounters bore a long-range social impact (see Table 1). As shall be demonstrated below, beyond the numerical demographics, these relationships had the potential to generate three family forms - the more commonly identified one of the enslaved mother and her children; those of the white father and his

Table 1 Percentage racial distributions of the Cuban population, 1775 and 1899

\begin{tabular}{lccc}
\hline Year & White & Black & Mulatto \\
\hline 1775 & 57.2 & 28.5 & 14.3 \\
1899 & 67.0 & 14.9 & 17.4 \\
\hline
\end{tabular}

Sources: For 1775, Humbolt, Ensayo político sobre la Isla de Cuba and for 1899, de la Fuente, 'Race and Inequality', 135 and Castellanos and Castellanos, Cultura Afrocubana, 2: 355. 
biracial children; and the more nuclear unit of white father, enslaved mother, and their children. It is the latter two that deserve greater recognition, which this study begins to impart.

To accept these white/slave relationships in late nineteenth-century Cuba as instances of family formation and to compare them with similar situations in Brazil and the United States require an understanding of the unique ways 'family' can be reconceptualised and researched for slave societies. The standard methods for the identification of historical families in western societies have emphasised forms of legal affinity (e.g. marriage), publicly acknowledged biological connections (e.g. social paternity), and co-residence. Yet the limitations of applying these standards to slave populations are obvious. In the USA, the denial of legal identity for enslaved people precluded the official right to marry, leaving only the options of forming consensual unions or temporary sexual liaisons. ${ }^{17}$ Both of these options ultimately were controlled by slave owner oversight. Conversely, most Latin American slaves retained their legal personage and the marriage option. ${ }^{18}$ The existing Latin American research indicates initially high marriage rates for enslaved Africans and an unexplained decrease for the subsequent Creole generations. Despite the safeguards offered by Iberian colonial policy, unfavourable gender imbalances and slave owner interference influenced the tenuous condition of the Latin-American slave family. ${ }^{19}$ Throughout the Americas, familial co-residence was difficult to achieve and maintain. Enslaved spouses were often separated from one another, as they were also from their offspring. As a result, evidence of slave families remains often obscured and a subject of considerable historiographic debate.

Proof of interracial families involving slaves suffers similar documentary challenges, which are exacerbated by the unique social taboos and legal restrictions such families faced in many regions. For example, the late eighteenth-century US case of Thomas Jefferson and Sally Hemings has been examined from opposing analytical perspectives regarding what constitutes acceptable proof of its existence. Even before the availability of supportive DNA evidence, those accepting the Hemings-Jefferson relationship had relied upon both printed allegations and family oral histories as the primary grounds for their position. ${ }^{20}$ By contrast, sceptics of the Hemings-Jefferson relationship cite the lack of Jefferson's own statements of paternity or public expression of interest in Hemings' children as the most damning indictment against his biological relationship to them. ${ }^{21}$ In the end, the difference between the two stances appears to rest on the former group's greater awareness of the subaltern nature of these experiences and their subsequent willingness to deviate from narrower standards of historical evidence. There, the existence of a family is confirmed primarily from loosely defined evidence of co-residence and a preponderance of voices within the community.

However, Hemings-Jefferson sceptics allow no such evidentiary flexibility and require that proof of interracial family bonds during slavery conform to the patriarchal standards suitable for documenting more normative families. Based on these criteria, the existence of such non-traditional families would receive modern confirmation only as the result of an earlier willingness of powerful men to document them publicly. This 
methodological preference thus rejects as unfounded claims of significant interracial affinity present in the oral genealogies of black families who acknowledge white progenitors and leaves such sources without any systematic treatment. For many scholars, the accuracy and legitimacy of these oral histories remain in question. For these reasons, only a few such families have been added to the U.S. historical record, generally only after the fathers' wills reveal their presence. This historiographic dearth has occurred despite numerous commentaries on the sexual relations between white men and enslaved women.

\section{Latin American sources}

A distinct set of Latin American perspectives and sources offers alternatives not seen in the US historiography, and the analysis of interracial families under slavery in Cuba suffers from fewer evidentiary problems than does its US counterpart. For much of Cuba's slaveholding period, no official marriage prohibition segregated race and status. Not only did free people mate and marry across social boundaries, but slaves also did so in small numbers. ${ }^{22}$ Despite Spain's 1776 Pragmatic Sanction against unequal status marriages - which enabled concerned relatives of potential marital partners to seek state intervention into any inter-status marriage of which they disapproved - multi-racial families continued to form consensually and through other legal methods. ${ }^{23}$ Fortunately, the difficulties attendant in recovering histories of such families can be overcome by two characteristics unique to Latin American slavery. First, the much debated maintenance of a legal personality for enslaved people (first described by Frank Tannenbaum) enabled them to exist as more than chattel property and allowed them to appear as active subjects in a variety of legal documents. ${ }^{24}$ Second and most directly related to the reproductive issues discussed here, evidence of family formation involving enslaved women and white men emerges from the surviving filial recognition documents. These petitions reflect the transfer of medieval Iberian family law into the Americas. ${ }^{25}$ As with Don Franco's above petition, in such recognitions, a father assumed the full measure of parental authority over the child born outside of wedlock, extended inheritance rights, and expressed responsibility for the child's proper upbringing. In rare cases, mothers also initiated such petitions, either for situations where their maternity had not been registered in the initial baptisms or for fathers who had died before claiming paternity themselves. Each parent could establish an independent legal connection to a child, without reference to the relationship existing with the other parent. A child acknowledged in this fashion could therefore belong to two separate families: one headed by the father and another by the mother. For a few of these children, parental co-residence allowed for a third family type, the more nuclear one with both mother and father.

The child receiving these rights was classified as a hijo natural reconocido (recognised natural child), which indicated that despite the parents' unwed state, no legal impediment to the marriage had existed at the time of conception. This classification was distinct from that of the hijo ilegitimo (illegitimate child), whose parents had faced a marital prohibition when the child was conceived, and also differentiated from the 
even more disgraceful hijo adulterino (child of adultery). ${ }^{26}$ In colonial Latin America, the hijo natural reconocido occupied an intermediate space between the illegitimate one and the child born of legitimate marriage. These children knew both their maternal and paternal ancestry, and were not 'bastards' in the English sense of the term.

In a recent pioneering study of such 'natural' children in nineteenth-century Brazil, Linda Lewin notes their centrality in expanding scholarly notions of the Latin American 'family'. She proposes that:

scholars attempting to account for a high incidence of births out-of-wedlock at all social levels in Iberian societies should start with the important clue that the inheritance system failed to exclude offspring born of merely illicit, but not 'damnable and punishable', unions ... In practice parents reared legitimate and illegitimate (particularly natural) siblings in the same households. Whether in two-parent or single-parent households, natural offspring often led fully integrated family lives indistinguishable from those who were born legitimate. Yet much of the historical literature holds that 'illegitimate' offspring testified either to the fragmentation inherent in the polygamous family or to the routine abandonment of children of 'casual unions'. We must revise such a view and give the organisational contexts in which the country's enormous population of natural offspring lived the central attention that they deserve. ${ }^{27}$

This understanding of 'natural' children would avoid unproductive comparisons of Latin American families to northern European ones and promotes the valuing of locally specific patterns. ${ }^{28}$ Unfamiliarity with the importance of hijos naturales to Latin American social practices and an impractical expectation of documentary conformity with unsuitable foreign standards, obscures many Latin American family forms, especially those born of white fathers and slave mothers. Again, while this conclusion is common in the historiography dedicated to several American slave societies, the contextual rationale in each is unique. Table 2 provides an abbreviated summary of these differences for the Cuban, Brazilian, and US scholarship.

\section{Alternative Cuban families}

Non-marital paternal recognitions were prevalent across late colonial Cuban society; all population segments - the elite, more common whites, free people of colour, and the enslaved - availed themselves of the practice. Social, economic, and cultural distinctions did not prevent paternity claims in any one group - although enslaved men obviously found them more difficult to execute. Even though Iberian protection of an enslaved person's legal identity allowed for the extension of familial bonds and inherence rights to offspring born of white/slave relations, such children comprised only a small subset of the total recognised outside of wedlock. Cross-racial filial recognition did not exist unchallenged. After 1805, Cuban Church officials interpreted the 1776 Pragmatic Sanction's restriction of marriages (against partners of unequal status) as a religious impediment that prevented white men from acknowledging paternity for their mulatto children. Moreover, despite an 1837 royal decree permitting all recognitions to which fathers attested, the Church continued to give the Pragmatic Sanction priority. It was not until 1860, when an angry white father demanded his 
Table 2 Historiographic treatments of relationships between slave mothers and white fathers in the Americas, during the nineteenth century

\begin{tabular}{|c|c|c|c|}
\hline & Cuba & Brazil & United States \\
\hline Form of government & Colony & $\begin{array}{l}\text { Constitutional monarchy, } \\
1822-1889\end{array}$ & Federal republic \\
\hline $\begin{array}{l}\text { Slaves' legal } \\
\text { personhood }\end{array}$ & $\begin{array}{l}\text { Humanity preserved } \\
\text { with limits }\end{array}$ & $\begin{array}{l}\text { Humanity preserved with } \\
\text { limits }\end{array}$ & Chattel \\
\hline Slave marriage & $\begin{array}{l}\text { Legally permitted, } \\
\text { restricted by slave } \\
\text { owners }\end{array}$ & $\begin{array}{l}\text { Legally permitted, } \\
\text { restricted by slave } \\
\text { owners }\end{array}$ & Prohibited \\
\hline Interracial unions & $\begin{array}{l}\text { Marriages restricted by } \\
\text { law as of } 1776 \text { and } \\
\text { social taboo; } \\
\text { consensual unions } \\
\text { common }\end{array}$ & $\begin{array}{l}\text { Marriages restricted by } \\
\text { social taboo; } \\
\text { consensual unions } \\
\text { common }\end{array}$ & $\begin{array}{l}\text { Prohibited by state law } \\
\text { and violently } \\
\text { opposed; a few } \\
\text { consensual unions } \\
\text { conducted in } \\
\text { secrecy }\end{array}$ \\
\hline $\begin{array}{l}\text { Historical sources } \\
\text { related to multi- } \\
\text { racial families }\end{array}$ & $\begin{array}{l}\text { Paternal recognitions } \\
\text { baptisms fathers' } \\
\text { wills limited oral } \\
\text { histories in white and } \\
\text { mulatto families }\end{array}$ & $\begin{array}{l}\text { Paternal recognitions, } \\
\text { baptisms, marriage } \\
\text { records, fathers' wills }\end{array}$ & $\begin{array}{l}\text { African American oral } \\
\text { histories fathers' } \\
\text { wills }\end{array}$ \\
\hline $\begin{array}{l}\text { Outcome for slave } \\
\text { mothers }\end{array}$ & $\begin{array}{l}\text { Potential acquisition of } \\
\text { freedom }\end{array}$ & Unknown & Continued servitude \\
\hline $\begin{array}{l}\text { Designations of } \\
\text { interracial } \\
\text { offspring }\end{array}$ & $\begin{array}{l}\text { Free mulatto, enslaved, } \\
\text { or white }\end{array}$ & $\begin{array}{l}\text { Free mulatto, enslaved, or } \\
\text { possibly white }\end{array}$ & Enslaved, black \\
\hline $\begin{array}{l}\text { Historiographic } \\
\text { tendency }\end{array}$ & $\begin{array}{l}\text { Only recent scholarly } \\
\text { assessment of slave } \\
\text { reproduction }\end{array}$ & $\begin{array}{l}\text { Miscegenation accepted } \\
\text { as foundational, but } \\
\text { not given to systematic } \\
\text { study }\end{array}$ & $\begin{array}{l}\text { Emphasis on violence, } \\
\text { inattention to the } \\
\text { concept of family }\end{array}$ \\
\hline
\end{tabular}

right to acknowledge his mulatta daughter, that the Church rescinded its prohibition. ${ }^{29}$ In the next year, in the first petition to involve a white father and an enslaved woman, the Bishop of Havana expressly stated, 'no concurrir impedimiento alguno para contraer matrimonyo ...' (no impediment existed to the marriage). ${ }^{30}$ From that year forward, these fathers actively sought legal guarantees of their families' existence, and the biracial Cuban children receiving such recognitions were less alienated from their white ancestry than some of the earlier histories of Latin-American race relations had posited. ${ }^{31} \mathrm{On}$ the eve of general emancipation and at a time of increased general anxiety surrounding the future of Cuban race relations, their families adapted to the decades-long abolition process utilising whatever mechanisms favoured their members. ${ }^{32}$ The personal stories of families created by slave mothers and white fathers reveal the unexpected results of their intimate negotiations of Cuba's transition from slavery.

\section{The fathers}

We turn first to the fathers. In a racially complex society such as late colonial Cuba, the process of identifying white fathers from the historical data has to be done with care, 
since documentary indications of 'whiteness' rest on a few key clues. Ecclesiastical registries for baptisms, marriages, and burials were separated by colour for much of the colonial period, with different sets for whites and for pardos and morenos. By the nineteenth century, the honorific title 'Don' was conferred to most white men, further differentiating them from free men of colour. This practice had not occurred previously. Rather, during the seventeenth and eighteenth centuries, 'Don' had been reserved exclusively for the use of the nobility; plebeian Creole whites appeared in ecclesiastical documents of that earlier period without titles or any markers of colour, blurring the indicators of their legal separation from free people of colour. In all cases, whiteness for commoners was established with more certainty for Spaniards, as birthplace was listed in Church records. ${ }^{33}$

Beyond consistent markers of racial identity, the paternity petitions demonstrated considerable variation in the geographic origins of the white fathers who initiated these claims. A slight majority were peninsular Spaniards, not Cuban Creoles. Of the 45 fathers, 27 were Spanish immigrants, one a New Orleans native, and one a Frenchman. These proportions are consistent with the Cuban popular history of miscegenation and with suppositions that immigrants were less likely to feel the conformist pressures of family members in matters of social conduct. ${ }^{34}$ Nonetheless, the significant number of Creoles in the data is at odds with Cuban popular notions that white Creoles did not enter relationships with women of colour. There was a continuing imbalance in Cuban gender ratios, in which white men significantly outnumbered white women, and socially enforced white female monogamy limited the possibility of racial endogamy for white males, regardless whether they were Creole or peninsular. ${ }^{35}$

The fathers' occupations, reported in 28 cases, also varied, ranging from agricultural labourers, urban property owners, and rural planters. However, because each father's description was unique, it is difficult to outline the characteristics typical of the white fathers who acknowledged children born to enslaved mothers. The only distinction was a slightly greater proportion of Spaniards; in few other areas were the fathers alike. For example, standing in stark contrast to Don Francisco Franco's complex case was a more straightforward 1874 one presented by Don José Rudecindo Valdés. He briefly described, in what appears to be his own hand, the family backgrounds for himself and the parda mother of his two young children. He then offered the requisite statement that the couple had been free to marry. Not surprisingly, his petition was easily approved; yet two elements of the case stand out. First, because no record exists of Don José's occupation, his social status is unclear. Second, Don José declared paternity of his two young daughters during a visit to their home in Havana, even though he resided over a hundred miles to the west in the small community of San Juan y Martínez, in the province of Pinar del Rio. With no additional information to explain that separation, it is impossible to determine whether the parents maintained a relationship, although Don Josés petition occurred within a month of the birth of the last child. ${ }^{36}$ Don José's case underscores that co-residence was not a prerequisite of legal family formation; distance did not prevent this white father from establishing a legal connection with his mulatta daughters. 
Don Josés petition is also typical of the others in that he did not own his daughters' mother. ${ }^{37}$ Only nine slave owners claimed paternity in these petitions. Yet, even their very formulaic petitions provide nuanced pictures of the men who combined slaveholding and fatherhood. The social status of these slaveholding fathers is obscured in the petitions. It is difficult to determine whether any were prominent men. No noble titles were seen in their ranks. A few described themselves as property owners or planters, but little is known about the size of their holdings. It is possible that they were among the large number of late colonial Cubans who only held one or two slaves. ${ }^{38}$

Most notable among the claims of self-described property owners is that of Don Tomás de Rocha y Martel, whose 1878 petition declared paternity of eight children born between 1862 and 1876 with an enslaved parda woman simply listed as Dominga. Each of the five baptismal certificates issued before Cuba's 1870 law of free birth stated that the child had been registered 'libre segun dispenso de su dueño Don Tomás de Rocha' (free according to the dispensation of her owner Tomás de Rocha). ${ }^{39}$ However, Dominga never received that concession, leaving unanswered many of the same questions with which we started. To what extent was their union based on affection or control? To what degree was Dominga voluntarily involved? And how did Dominga and Don Tomás divide the responsibilities of child rearing? Unlike the Hemings-Jefferson case, where the very existence of a master-slave family is debated, Don Tomás confirmed the legal reality of his family and accepted a legal responsibility to nurture and educate these children. He also conformed to what appears to have been a Cuban social taboo against fathers publicly holding their own progeny in slavery. Of children born before the 1870 Free Womb law to the master-slave pairs in the ecclesiastical petitions, none were baptised as enslaved. In each case the father provided a carta de libertad (letter of freedom). These men simultaneously maintained and diminished the familial distance between whiteness and slavery through their progeny.

Other slave-owner paternity declarations appear more modest than Don Tomás'. Two of the petitioning fathers described themselves simply as labourers. Don Juan Antonio Alcala y Díaz, a Canary Islander, claimed paternity 38 years after his daughter's 1840 birth to an African woman whom he owned at the time of her birth. He had granted the child's freedom at her birth, and the timing of the petition argues that Don Juan maintained a connection with his daughter into her adulthood. It is not clear how he explained his one-time relationship with her mother, especially to his wife, who he had married in 1853, well after his daughter's birth. ${ }^{40}$

The case of Don Pedro Tribarreau, a Basque carpenter living in Havana, was very distinct. His former slave and son's mother, Caridad, was the one to initiate the ecclesiastical petition, after she had gained her own freedom. Her 1880 ecclesiastical request occurred three years after Don Pedro's notarial recognition of their three-year-old son. ${ }^{41}$ Unlike other formerly enslaved women of the period, Caridad was not described as 'patrocinada' (apprenticed). In the last stage of Cuba's general transition from slavery to wage labour that occurred between 1878 and 1886, formerly enslaved people were given this intermediate designation, as their masters were to prepare 
them for emancipation. That Caridad was listed instead as a 'morena libre' (free black woman) suggests that Don Pedro had granted her freedom at some date between his 1877 notarial declaration, in which she is described as a slave, and her 1880 petition where she listed herself as free. Several possible explanations exist. Caridad may have purchased her own liberty, or perhaps Caridad had gained that concession as a reward for the couple's sexual relation. On the other hand, affection or love for Caridad may have prompted Don Pedro to grant her freedom. Again, the documents do not divulge a definitive explanation.

\section{The mothers}

As would be expected, the power of slave women to control documentary expressions of family bonds differed markedly from that of white fathers. Caridad's case is exceptional among the Church documents for demonstrating the initiative taken by a formerly enslaved woman. In most cases a father initiated the paternity declaration. Therefore, the filial recognitions were heavily biased toward the fathers' concerns and generally offer only limited information about the mothers. Yet, status, origin, and colour were consistently reported for these women, giving a sense of how these markers were perceived within the general society and employed by the petitioners. For Cubans of colour, the documents emphasised two principle colour categories: moreno (black) or pardo (brown or mulatto). Unlike the English use of the term 'mulatto', which describes a person with one black parent and one white parent, the nineteenth-century Cuban term 'pardo' referred to anyone with a discernible combination of African and European ancestry. It was less a marker of phenotype, than of distinction from either pure African or pure European social backgrounds. ${ }^{42}$ For this reason, the pardas described in the recognitions could have covered a vast phenotypic range, from very dark to nearly white.

The 19 pardas registered as mothers in the 45 cases were slightly outnumbered by the 23 women described as morenas criollas (black Creole women). Two additional women were reported as Africans. ${ }^{43}$ The near equal presence of parda and morena women allude to a white male preference for establishing unions with enslaved pardas, given the fact that during the nineteenth century, enslaved black women outnumbered their mixed-race counterparts by a significant proportion. ${ }^{44}$ This statistical allusion to a greater percentage of racially mixed women involved in interracial contacts correlates to the late colonial popular image in which the mulatta was portrayed as rejecting potential marriages with black partners in favour of maintaining consensual unions with whites. ${ }^{45}$ Despite this image, however, one must be careful to be ever cognisant of the extent to which enslaved parda women were victimised and unable to limit sexual encounters with white men. One paternity petition expressly highlights the power relations surrounding interracial sex during slavery. The 1868 baptismal certificate of a daughter born to parda Camila and her master noted that 'the petitioner desires that she remain his slave until his death and verifying this, the child is free. ${ }^{46}$ While this father freed his child, the mother was not as fortunate. This slave owner exhibited both generosity and possessiveness that were directed in very pointed 
ways. In either case, the patriarchal nature of slavery remained unchallenged as final authority remained with the slave owner. ${ }^{47}$

Slave mothers began their connections to their children's fathers in a variety of settings. Of the 45 cases, 23 emerged from urban Havana, but rural plantations and small towns gave rise to the remainder. This distribution reflects the diversity of slave experiences common in late nineteenth-century Cuba. Enslaved people were not limited to sugar plantations, which accounted for $47 \%$ of slave production at its height. ${ }^{48}$ Other, less labour-intensive agricultural enterprises - such as coffee, tobacco, and cattle ranching - also utilised slave labour. Additionally, slave women's employment as domestics, washerwomen, seamstresses, street vendors, and prostitutes existed in both urban and rural environments. These women were not often segregated exclusively with other enslaved people. They moved through multi-ethnic, multi-status social spaces that created opportunities for bonding with different categories of men and offered the possibility of earning a small, independent income useful in the purchase of freedom. ${ }^{49}$

Such was the case of another Camila, the black slave nurse at the Intrépido plantation in Matanzas province, who saved sufficiently to purchase her daughter's freedom in 1876. She generously did so even before she had liberated herself. The 16-year-old Brígida continued to live with her slave mother on the plantation and caught the attention of one of the white workers, Don Vicente Refo. Brígida and Vicente were intimately involved for two years despite the plantation owner's dismissal of his imprudent employee. In a final effort to end the relationship and to protect Brígida from such 'persecutions and seductions', the plantation owner, the Marquis de San Miguel, sought her placement in a public house for wayward young women, a place generally reserved for whites. ${ }^{50}$ Life on a rural slave plantation was not a monolith for either mother or daughter. Both created their own possibilities within it. However, even in her freedom from enslavement, Brígida was still subject to white control. One was a form she consented to willingly with her lover, Vicente, and another emerged from the Marquis' paternalistic vigilance. From such mixing of white, Asian, free coloured, and slave labourers, familial relations often grew, even in the sugar plantations more typically described for their harsh, unrelenting labour regime. Juana Fundora, had been a field slave on the Callajabos sugar plantation when she began a relationship with the farm worker Don Luciano Ramos. The pair remained together from the birth of the first of their six children in 1856 until Luciano's death in 1886 , at age $60 .{ }^{51}$ Plantation slavery had not prevented Juana's establishment of a long-term consensual union. Brigida's and Juana's outcomes demonstrate private and intimate versions of the negotiations occurring between people of colour and whites that modern scholars frequently have considered for slavery's more public practices. ${ }^{52}$ Slave women were not always victims, and not all white men cruel in their actions. Under the appropriate conditions, affectionate bonds developed across both race and status categories.

Ten mothers appearing in the 45 paternity declarations gained their freedom before 1878 , the date at which adult women were included more actively in the ongoing gradual emancipation process. ${ }^{53}$ Half were described as morena, including one 
African woman. The high proportion of pardas in this sample is again consistent with anecdotal emphasis on parda women's social advancement through liaisons with white men, given that they represent only $42 \%$ of the mothers in this data set and a small proportion of the general female slave population. One nineteenth-century Spanish traveller to Cuba commented, 'if (mulatto women) were not already free, they freed themselves by pairing up with white men. ${ }^{54}$ Caution must be used, however, as these women may also have utilised other mechanisms to acquire freedom.

The complex paths of self-liberation that some slave mothers had to negotiate are seen in the legal proceedings that surrounded the family of parda Juana González. Unlike the images of family unity and rare female assertiveness generally found in the ecclesiastical records, Juana's case before the sindico procurador (state-appointed legal advocate for slaves) revealed one woman's steadfast pursuit of justice. As a young woman Juana had become romantically involved with her owner's son, Francisco. When she became pregnant, Francisco initially pledged to her that the infant would be baptised as free. Instead, Francisco failed to complete his promise. As Juana reached the last months of her pregnancy, the González family forced her to marry against her will to another slave. When her daughter María Quirina was baptised, that new slave was listed as the father in Francisco's place. Juana was later sold to a new owner, while the infant remained in the care of the González family. Twenty-eight years later, Juana had purchased her own liberty and then used Francisco's unfulfilled pledge as the grounds for her appeal to the sindico procurador for her daughter's. To counteract the damning, but false, evidence in her daughter's baptismal certificate, Juana applied a phenotypic logic - saying that the black legal father could not have produced someone of María Quirina's characteristics, 'when she is so fair, with such straight hair'. The court found in Juana's favour. Don Francisco acknowledged his paternity and compensated his family for the price of María Quirina's liberty, along with that of a nine-month-old son born to her. ${ }^{55}$ Despite the reluctance with which he demonstrated them, Don Francisco's familial bonds to María Quirina and her son ultimately earned them their overdue and hard-fought-for freedom.

Although the ecclesiastical petitions often contain less direct explanations of the mothers' transition to freedom, they allude to that process. ${ }^{56}$ Such was the case of María de Jesus Silvera. Although she was African, she was free by the time of her son's birth in $1853 .{ }^{57}$ She may have achieved her freedom in any one of several ways. In addition to the more typical possibilities of self-purchased freedom or owner's manumission, a third option existed in this case. María de Jesus may have been an emancipada, an African whose enslavement was deemed illegal because of her importation after the close of the legal slave trade in 1820. In December 1853, the island's incoming lead colonial officer, Captain General Juan Pezuela decreed free all emancipados who had completed an obligatory five-year labour and acculturation period. ${ }^{58}$ Again, unfortunately, the documents generally do not indicate how freedom was obtained. That slightly more than a fifth of the slave women involved in these interracial relationships were liberated is suggestive of a material benefit of these relationships. Perhaps the women had received the assistance of their white partners. However, few comments directly verify that possibility, and until the pre-1878 
manumission rates for Cuba's slave population are more generally determined, any measurement of the relative benefit of interracial relationships for enslaved women remains speculative. ${ }^{59}$

Status changes were seen most easily for mothers of multiple children by the same claimant partner or for mothers who appeared on multiple occasions within the records. The family of Eulogia Montalvo highlights one exceptional example of this complexity. This family's experiences reveal the types of transformation of status and racial identity that appear with document linkage across several types of ecclesiastic source. Eulogia first appeared in the documentary record in 1867, at the Havana parish of Espíritu Santo, in the baptism of her daughter, Mercedes Tavira. At that time, Eulogia and her legitimate husband José Loreto Junco were owned by Doña Dolores Tavira, and thus, the child was also an enslaved 'morena', who received her owner's surname. ${ }^{60}$ Eulogia also had an active presence in the records as the mother to other, mixed-race children. After Mercedes' 1867 baptism, Eulogia had at least five other children beginning in 1872. Unlike Mercedes' legitimate status, these children were initially baptised without a father listed. Given that baptismal certificates of the period generally registered slave mothers only by their first names and the names of their owners, family continuity across records is often elusive. Documentation of the familial connection between Mercedes and Eulogia's other children derives from the unusual listing of the same maternal grandparents for each. Interestingly, all of these younger children were categorised as pardo, in contrast to their mother's and older sister's morena status. ${ }^{61}$ This pardo classification was explained later, in 1881, when the younger children were formally acknowledged by their Spanish father, Don Manuel Rodríguez y Vázquez. While clarifying the children's paternity, the couple stated that they had not married earlier specifically because of a legal 'impediment that prohibited it'. It is likely that this restriction emerged from an application of the 1776 Pragmatic Sanction. That Eulogia was widowed and Don Manuel was a bachelor together eliminated some of the more typical canonical objections.

The case is also interesting in that Eulogia did not acquire her freedom as the result of her relationship with the Spaniard, even though the couple continued to live together through the birth of several children. At the time that the paternity petition was submitted, like many other formerly enslaved women, Eulogia had become a patrocinada and thus apprenticed to her old owner in the last stages of slavery before probably gaining her freedom with the 1886 general emancipation. ${ }^{62}$ The acquisition of her own liberty and the paternal recognition for her children were not the only elements of family identity divulged in Eulogia's records. They also indicate that she took steps to ensure that the children's maternal ancestry was also properly recorded. Just prior to Don Manuel's recognition of the children's paternity, Eulogia also petitioned for a change in the family's surname, from Gaston, which belonged to one of her previous owners, to Montalvo, which her father had received after arriving from Africa. ${ }^{63}$ She explicitly declared that she wanted his identity properly recorded, perhaps so that it would not become lost to the neglect with which Cuban ecclesiastical documents typically treated African ancestry. Thus, this family 
made the transition from slavery while reclaiming both the African and European sides of its identity. These actions and the union of legitimate and 'natural' children into the same households support calls for a more comprehensive view of the Latin American family, one seen in terms of its own reality and not measured against marital and coresidential forms.

\section{Children and their variable social identities}

The children of these white-slave unions faced many of the same concerns as their mothers. The 45 pairs of slave mothers and white fathers in these records sought paternal recognitions for 113 children, 61 sons, and 52 daughters. Many realised similar status transformations seen for their mothers. With the 1870 Moret law, no child was born into slavery. Prior to its application, parents endeavoured to position their offspring favourably, despite the social constraints acting against them. It may not have been uncommon for white fathers to remove the stain of slavery from the children born to them by enslaved mothers. The sources at times demonstrate white fathers and slave mothers acting as joint participants in that project. Before the 1870 law, half of the children born to the 45 pairs in this study were baptised as free. In one of these cases, the child's 1855 baptismal record noted that 'the child was baptised as free in virtue of the free parda owner having received from [his mother] the slave Angela the sum of 25 pesos from the time of pregnancy for the liberty of her child.6 In this way, one law, the right to purchase freedom, superseded another, the partus sequitur ventrem, in which the condition of the child follows that of the mother. ${ }^{65}$ The ambiguity related to the origins of Angela's 20 pesos should caution against the conclusion that the French father, Don Pedro Goin, was the exclusive source of these funds. Even if that were the case, Don Pedro did not assist Angela in a similar fashion. She was still a slave at the date of the paternity declaration, 22 years after her son's birth. Yet in using such situations to their advantage, these families socially united enslaved and free people. Enslaved women raised free children, as their white fathers took legal responsibility for them. At times the parents were united in the same households; in others they were not. In acknowledging his 10, free adult children, one father who was also the mother's slave owner spoke with pride about having 'educated them with an affinity for personal hard work, and the necessary respect for society and the laws of the nations'. He believed his efforts effective as 'the public received them well, because of their comportment and religiosity. ${ }^{66}$ His words subtly imply that he had sought to distinguish his daughters and sons from what he perceived as the common behaviour of other mulattos and, once demonstrated, they merited both public respect and his legal recognition. This is the simultaneous corruption of the vision of mixed-race identity and a reinforcement of its logic. His children were no ordinary mulattos, as he saw it. They were exceptional because of his positive socialising input, beyond the value of white biological ancestry.

What of the children who had remained enslaved prior to the retroactive application to September 1868 of the Moret law? What were their connections to their fathers? Don Nicolas Sanchez y Liaño's paternity petition explained that the first of his three 
children born to the one-time slave Juliana was born also enslaved. By the time their second child was born, Juliana had gained her freedom. Nevertheless, no mention of a change in status for the first child was part of the petition package filed 11 years after her birth. ${ }^{67}$ For children of this type, their fathers' paternity claims created an intimate, familial connection between white identity and slavery, in ways that went beyond economic concerns and direct racial control.

Many of the paternal declarations in these cases occurred several years after the children's births, during the abolition of Cuban slavery. For example, in 1886 Spaniard Don Antonio Nazabal claimed his mulatto son Prudencio, 30 years after the latter's birth. Although the documents do not indicate the type of relationship the two had maintained in the interim, the two enjoyed that year's final abolition together. ${ }^{68}$ While this petition was unclear about the continuing contact between the parents, others reveal long-term co-residence and, less often, later marriage. Even with the 1881 abrogation of the restriction against unequal marriage, such marriages were exceedingly rare. Only two couples in this collection later formalised their union. ${ }^{69}$ In one such 1893 case Don Andrés Canito y Navarro, a labourer from the Canary Islands, married the parda former slave Marta Perdomo and legitimated their children. The petition testified 'for more than 50 years, they had lived together illicitly, without any impediment [to marriage] other than being of distinctive races'. Before final abolition, this had been a poor family with both free and enslaved members. The paternity declaration indicated that the couple were 'pobre de solemnidad' (the solemn (and respectable) poor), who could have justifiably received crown or church assistance. Yet, the family had made a significant financial investment in one of its members. The 1851 baptismal certificate of the couple's first child described her path to freedom; 'Her owner, Don Antonio Trujillo, has provided a "carta de libertad" (a letter of freedom) to the child for having received from her father Don Andrés the quantity of money decided by both'. He and Marta did not purchase the liberty of three subsequent sons, who were each baptised as enslaved. Yet, they, their white father, free sister, and enslaved mother maintained a common bond, as the delayed paternity attests. ${ }^{70}$ It is perhaps the acquiescence to the primacy of slave owner authority that partially explains Don Andrés' belated assumption of parental responsibilities, with the paternity declaration left to the post-abolition period. The only concession Spanish law had made to white fathers of slave children was to establish in the early colonial period the right of first purchase if the owner wished to sell. ${ }^{71}$ Poverty limited this option for Don Andrés. Many other poor white fathers probably did not possess the resources needed to legally recognise their children nor to liberate them from slavery.

The public identities of families involving enslaved women and white men were not always determined in straightforward ways. There were a number of parents who bent the social codes and removed their children from slavery in alternate, more circuitous ways. Don Francisco Franco's case that opened this paper was just one example of that behaviour. Three additional recognition petitions also disclose the fathers' confessions of intentionally falsifying their children's race. One instance is found in the relationship formed by Spaniard Don Bernardo Arango y Díaz and Carlota Cruz. Its initial 
documentary presence would suggest that it was a typical white Cuban family. Two children were born to the couple in 1869 and 1871, and both were baptised as white. Yet, this was a deliberate deception, as the mother's recorded background was later revealed to be untrue. She had been given a false white pedigree, with the claim that she had been born to an upstanding family in Mexico. The reality of her birth into slavery and parda identity were obscured. The truth only came to light in 1890 as the couple were about to marry and legitimate the children. At that point, the father confessed that his children had both somehow 'mistakenly' been registered as white. ${ }^{72}$ It is possible that the truth may never have emerged if not for two significant changes in Cuban society. The restriction of interracial marriage was repealed in 1881, and slavery abolished in 1886. After that date, the public markers of African descent would not curtail the social possibilities of blacks and mulattoes in quite the same ways. Nevertheless, it is probable that other cases of racial misrepresentation remained hidden within the records, as the families involved did not confess their deception as had Don Bernardo and Carlota. ${ }^{73}$

Likewise, the practice of using the Real Casa de Maternidad, royal maternity home and orphanage, to register illegitimate children as white allowed those of mixed descent to escape some racial limitations of their reality. Again, Don Francisco's family at the beginning of this paper engaged in this strategy, with his first daughter initially baptised as a white orphan. In another example, two of the three children of Spaniard Don Ramón Carriedo and enslaved parda Merced Barroso were baptised as white orphans. By requesting in 1863 that the children bear his name, Don Ramón also exposed the earlier deception. Church officials appear to have been lenient with the confession. The children were re-registered without any indication that they should have inherited their mother's slave status. ${ }^{74}$ Thus, with the assistance of their white fathers and the complicity of other members of their community, even the children of slave women could have achieved jural whiteness. Notions of white racial purity were corrupted by this practice. Paternal recognitions did not generate the practice, but the investigation of the surviving records makes some aspects of those deceptive and socially transformative practices visible.

\section{Conclusion}

Ultimately, the interactions of enslaved women and white men covered a range of behaviours. Much attention has been given to their sexual relationships. While some commentators have stressed violence and power in those experiences, others have depicted the social benefits that enslaved women gained as participants. Few discuss the results of these interactions in terms of the establishment of familial bonds. It is not that there was an absence of such families or a lack of contemporary popular awareness of them. These families simply did not generate the documentary evidence typical of European family forms. Therefore, historians have been left with only anecdotal comments about a few families' experiences. No overall sense of the sociological value of these families had previously been distilled from the very dispersed nature of these sources. 
A set of under-utilised, ecclesiastical sources offers an alternative for the study of families involving white fathers and enslaved mothers in Latin America. They result from the transfer into the Americas of medieval Iberian laws that gave paternal recognition to children born out of wedlock. In those acknowledgements of paternity, men proclaimed responsibility for the nurturing, education, and welfare of their nonmarital children, as they also guaranteed inheritance rights. Therefore, while they were born outside of marital unions, these children did not live as 'bastards' as one might imagine conceptualised in English usage. Connections to both their maternal and paternal heritage were legally defined. These recognitions were utilised across the social spectrum, from wealthy planters to the working class.

While the legal possibility of such acknowledgements may have diminished much of the social pressure to marry for social classes of Latin America, they may have had a unique purpose in nineteenth-century Cuba. They may have been used to circumvent the restrictions on unequal or interracial marriage generated by Spain's 1776 Pragmatic Sanction. The early nineteenth-century turn toward independence in continental Spanish America left only Cuba and Puerto Rico to experience its full weight. With the sanction, cross-racial unions that previously had been limited only by social taboos were then legally curtailed. This restriction did not prevent the establishment of interracial relationships, however. Many still existed outside of legal documentation; and by 1860, white Cuban fathers regained the right legally to claim their mixed-race children, and a few of their familial bonds with enslaved women reappeared in the historical record.

The documents generated by these paternity declarations are less valuable in revealing the rates of intimate cross-racial interaction than for presenting unexpected moments in the social construction of race. During the second half of the nineteenth century, with the rapid shifts in Cuban race relations caused by the looming prospect of slavery's abolition, they reveal the affectionate connections and processes of family formation forged on the social margins between enslaved women and white men. The births and recognitions of multiple children to such couples expose the long-term nature of many of their relationships. These cases were not ones of casual sexual encounters forgotten by men who had the power to ignore them. These experiences had lasting impact for fathers, mothers, and children. The high rates at which the women involved in these relationships gained their freedom hints at the assistance of their white partners, although the women's own agency in that process was also essential. Unfortunately, neither do the documents permit an assessment of the emotional factors in these situations. Violence and control cannot be ruled out in many cases. The maintenance of some relationships after the abolition of slavery suggests other motives, and the subsequent marriages of a few couples also indicate more affectionate foundations. Regardless of the reasons for these unions, they decreased the social separation of whites and enslaved people.

Similar results emerge as one focuses more closely on the children of these unions. Many parents endeavoured to position their offspring in socially favourable ways, despite the constraints acting against them. The white fathers and slave mothers in these sources often cooperated in those efforts. Regardless whether one defines these 
relationships in terms of rape, concubinage, or marriage, these white fathers procreated themselves through black and mulatta bodies and often exercised the power to mark these children's initial social identities. These children were categorised as either enslaved, free mulatto, or white, depending on the success of their parents' intervention. Half the children born of these relationships were born free, including all those born of the mothers' owners. For their slave mothers, perhaps this was a desired successful result or recompense for a situation over which they had little control. For the white fathers, perhaps this was a gift of love or an act of personal responsibility. The documents do not clarify the emotional impulse behind many of these acts. Liberation from slavery was only one important social concession made for many of these children. On a few occasions parents also successfully obtained an official white categorisation for their mixed-race progeny. That these parents did so with a degree of community complicity raises further questions about the meaning of whiteness in nineteenth-century Cuba. Its boundaries appear to have been loosely drawn, if even a few children of slave women could receive this legal designation.

To return to an earlier point, other commentators have suggested that the reason the Hemings-Jefferson paternity case has such popular and academic resonance is due to its ability to expose tensions between personal character and community values for one so central in forging the new nation's character. Similarly, unions of this type found throughout the Americas prompt a questioning of the allegiances chosen by white men living in slave societies, whether these commitments were to the nontraditional families they formed or to more abstract notions of their own racial superiority. As with all relationships on the social fringes, those established between enslaved mothers and white fathers during the waning years of slavery in Cuba existed in 'a world in which racial - and family - identity was both a matter of social ascription and painful [individual] choice. ${ }^{75}$ In analysing their exceptional practices with regard to the standard racial behaviours and categories, we gain a more nuanced, historically appropriate vision of that world and the links between the blacks and whites who (re)produced it.

\section{Notes}

[1] Redfield, A Succinct Account of Some Memorable Events, 9.

[2] Archivo del Archibispado de la Habana, Fondo Legitimaciones y Reconocimientos (hereafter Reconocimientos), legajo 36 expediente 56, 1875.

[3] With racial terms such as 'mulatta', this essay assumes a social constructionist approach, which de-emphasises the biological existence of race. I use racial terms in ways that allow for modern comprehension of their historical meaning. The case appears in Reconocimientos Leg. 36 exp 56, 1875.

[4] This study provides a social history complement to the labour history focus of Scott, Slave Emancipation in Cuba.

[5] Reconocimientos, Leg. 4 exp. 83, 1861; Leg. 5 exp. 49, 1862; Leg. 6 exp. 43, 1863; Leg. 23 exp. 27, 1871; Leg. 28 exp. 14, 1872; Leg. 30 exp. 67, 1873; Leg. 31 exp. 2, 1873; Leg. 34 exp. 54, 1874; Leg. 36 exp. 56, 1875; Leg. 43 exp. 26, 1876; Leg. 45 exp. 20, 1876; Leg. 46 exp. 56, 1877; Leg. 48 exp. 12, 1877; Leg. 51 exp. 17, 1878; Leg. 52 exp. 61, 1878; Leg. 53 exp. 17, 1878; Leg. 53 exp. 87, 1879; Leg. 58 exp. 20, 1880; Leg. 62 exp. 94, 1881; Leg. 65 exp. 90, 1881; Leg. 66 exp. 90, 1881; 
Leg. 67 exp. 51, 1882; Leg. 71 exp. 28, 1882; Leg. 73 exp. 53, 1883; Leg. 79 exp. 18, 1884; Leg. 80 exp. 11, 1884; Leg. 83 exp. 76, 1885; Leg. 85 exp. 61, 1886; Leg. 88 exp. 12, 1886; Leg. 88 exp. 25, 1886; Leg. 89 exp. 77, 1887; Leg. 90 exp. 13, 1887; Leg. 90 exp. 38, 1887; Leg. 93 exp. 1, 1888; Leg. 98 exp. 94, 1889; Leg. 99 exp. 7, 1889; Leg. 101 exp. 7, 1890; Leg. 101 exp. 42, 1890; Leg. 102 exp. 5, 1890; Leg. 102 exp. 20, 1890; Leg. 103 exp. 62, 1890; Leg. 103 exp. 63, 1890; Leg. 105 exp. 22, 1891; Leg. 110 exp. 44, 1892; Leg. 114 exp. 68, 1893.

[6] The archive of the Archbishop of Havana has served the island's western region since the beginning of the nineteenth century. This study reviewed 737 paternity petitions involving black or mixed-race children. These petitions are found in the collection Reconocimientos y Legitimaciones, Leg. 1 exp. 1, 1804 to Leg. 116 exp 61, 1893. The first recognition for a black or mulatto child dates to 1858 . Paternity declarations for white children emerged in this collection much earlier. The first appeared in 1804. There is evidence to suggest that earlier recognition petitions were managed at the parish level. According to Cuadrado Melo, Obispado de la Habana many of the parishes in Cuba's western ecclesiastical district kept their own records related to recognitions during the middle of the nineteenth century. Additionally, the baptismal certificates of many children of colour born outside of wedlock often list both parents as unknown.

[7] Murray, Odious Commerce; Aimes, A History of Slavery in Cuba; Saco, Historia de la esclavitud.

[8] My use of the concept of racialised reproduction benefits from a reading of McClintock, Imperial Leather and Stoler, Carnal Knowledge and Imperial Power.

[9] Petley, 'Legitimacy' and Social Boundaries', demonstrates the familial distance and limited material reward given by white fathers to their mixed-race offspring in early nineteenthcentury Jamaica. For studies noting the violence visited upon female slaves, see Davis, 'Reflections on the Black Woman's Role', and Women, Race, and Class, 22-26; Giddings, Where and When I Enter; White, Ar'n't I a woman?; and Baptist, 'Cuffy,' 'Fancy Maids', and 'One-Eyed Men'.

[10] Nash, 'The Hidden History of Mestizo America', gives a concise overview of the literature. Also see Menke, Mulattoes and Race Mixture; and Williamson, New People.

[11] See Slenes, Na Senzala, Uma Flora, ch. 1, and 'Black Homes, White Homilies' for a discussion of the crippling historiographic assumptions about disinterest in family life among Brazilian slaves.

[12] Freyre, The Masters and the Slaves especially chs 3 and 4. For an interpretation, see Needell, 'Identity, Race, Gender, and Modernity'.

[13] Degler, Neither Black Nor White, 226-232. Karash, Slave Life in Rio de Janeiro makes the claim that 'until they obtained their freedom, the children of a slave and her master lived 'bastards' in a large extended family to which they did not actually belong; yet their relationship to their master-father incorporated them within his large family in a manner that was more African than European', 298.

[14] The notion of an economic advantage enjoyed in twentieth-century Brazil by people of notable mixed-race descent has been attacked by several authors. In the anthropological literature, for an example, see Wood and Lovell, 'Skin Color, Racial Identity.' Historical analysis is less developed, but helpful considerations are offered in Skidmore, 'Race and Class in Brazil.

[15] A seminal work that laid the foundations for much of the colonial Latin-American race relations scholarship is Mörner, Race Mixture. While many of its interpretations have been superseded by new research, it continues to influence notions about the social positioning of persons of mixed-race heritage. For alternative approaches, see, for example, Burns, 'Gender and the Politics of Mestizaje'; and Cope, The Limits of Racial Domination.

[16] See, for example, Genovese, Roll Jordan, Roll, 415-419 for a discussion of a few of these unions.

[17] An extensive literature continues to assess the prevalence of 'nuclear, two-headed households' for slave population in the English-speaking regions of the Americas. Here, I cite the essential works on this issue. For the United States, Gutman, The Black Family in Slavery and Freedom; 
Malone, Sweet Chariot; and Stevenson, Life in Black and White. For the British Caribbean, Higman, Slave Populations of the British Caribbean and Craton, Searching for the Invisible Man.

[18] Tannenbaum, Slave and Citizen; Rout, The African Experience in Spanish America; and for Cuba, Klein, Slavery in the Americas; de la Fuente, 'Slave Law and Claims-Making'. Acceptance of the value of Iberian law on the nature of Latin American slavery does not preclude the inherent brutality of the system that some critics of Tannenbaum posit is minimised in his argument.

[19] Chandler, 'Family Bonds and the Bondsman' comments on the surprising stability of slave families in colonial Colombia. 'Slave families seem to have been limited only by the unfavourable sex ratio that prevented them from forming, rather than by their owner's or by society's indifference, hostility, or insensitivity or even by sale or economic considerations for that matter, which often sundered slave families in other areas', 127. More specifically for Cuba, see Barcia, La otra familia; García Rodríguez, La Esclavitud desde la Esclavitud; and Perera Diaz and Meriño Fuentes, Esclavitud, Familia, y Parroquia en Cuba.

[20] The most concise argument by those acknowledging the Hemings-Jefferson relationship is presented by the Thomas Jefferson Foundation, a non-profit organisation dedicated to the preservation of Jefferson's memory, in 'Thomas Jefferson and Sally Hemings: A Brief Account'. Also see, Woodson, A President in the Family; Lewis and Onuf, eds, Sally Hemings \& Thomas Jefferson and Gordon-Reed, Thomas Jefferson and Sally Hemings and The Hemingses of Monticello.

[21] The Thomas Jefferson Heritage Society, Jefferson-Hemings Scholars Commission, 'Report on the Jefferson-Hemings Matter', and Dabney, The Jefferson Scandals.

[22] Although marriage records were not reviewed for this study, the existence of interracial marriages in Cuba during the eighteenth century can be seen in the surviving baptismal records of mulatto children. For the intramural Havana parish of Espíritu Santo, between 1765 and 1768 nine Spaniards were listed as legitimate fathers in a total of 643 baptisms of mulatto and black children. The number of white, Creole fathers could not be determined, since those records rarely recorded the colour of the freemen. Spaniards were distinguished by the listing of their place of birth. De la Fuente, 'Matrimonios de esclavos en la Habana' also reports a small number of interracial marriages of the seventeenth century. Interracial marriage was restricted during the last century of Cuban slave holding, between 1776 and 1881 .

[23] Martinez-Alier, Marriage, Class and Colour.

[24] See items in n18 above. Additionally, de la Fuente, 'Slaves and the Creation of Legal Rights in Cuba' speaks of the recourse to legal mechanisms to improve their condition and gain freedom, utilised by nineteenth-century Cuban slaves.

[25] For the evolution of the rights of natural offspring in the nineteenth-century Brazilian law, see Lewin, 'Natural and Spurious Children in Brazilian Inheritance Law' and Surprise Heirs I, Kuznesof, 'Who were the Families of 'Natural' Children' describes 'natural' children as the products of co-residential, consensual unions, without legal definition. The Cuban material suggests more precise legal application of the term in nineteenth-century baptismal records. The local ecclesiastical recognition of natural children was distinct from the method of legitimisation through gracias al sacar described by Twinam, Public Lives, Private Secrets, 16, passim. The former was a procedure controlled by local ecclesiastic authorities and the latter required Crown approval.

[26] Since the medieval era, Castilian law had utilised the label 'hijo natural reconocido' exclusively for children born outside of marriage, where no legal or religious impediment prohibited the union of the parents. In designating an offspring as a 'hijo natural', the father who had been unmarried at the time of his child's conception accepted the responsibility and the cost of 'subsistence, nurturing, and education.' That child also gained the right to a maximum of one fifth of the paternal estate. References to the Ley de Toro 11 on this point are found in Portuondo de Castro, La filación, 7 and Gacto Fernández, La filación no legítima, 81, 131, and 140-141. Both 
free and enslaved men executed such declarations. Although enslaved men might not have had the ability to fulfil these obligations, freemen had to concern themselves with the legal ramifications.

[27] Lewin, 'Natural and Spurious Children', 383 and 386.

[28] The distinction of Latin American family forms from European models is well established in the literature. See, for example, Smith, The Negro Family in British Guiana; Arrom, 'Marriage Patterns in Mexico City'; Calvo, 'Concubinato y mestizaje en el medio urbano'; and PotthastJutkeit, 'The Creation of the 'Mestizo Family Model'. An examination of non-traditional families in late colonial Cuba created by men varied racial backgrounds (including blacks and mulattos) is found in Morrison, 'Creating an Alternative Kinship'.

[29] Reconocimiento, Leg. 4 exp. 57, 1860.

[30] Reconocimiento, Leg. 4 exp. 83, 1861.

[31] See, for example, Mörner, Race Mixture.

[32] Again, Cuban abolition evolved in five key stages: (1) the 1820 criminalisation of the African slave trade; (2) the 1868 liberation of the slaves of Cuban independence patriots; (3) the 1870 Moret Law that freed elderly slaves, children born to slave mothers after 17 September 1868, slaves owned by the Spanish government, and African emancipados who had been illegally transported to Cuba after 1820 ; (4) the 1880 patronato law creating an eight-year apprenticeship period to facilitate the transitions to wage labour; and (5) the 1886 final emancipation. See n.7 above.

[33] Compare, for example, the eighteenth- and nineteenth-century baptismal registers for whites in the Havana parish Santo Angel del Custodio, Libro de bautismos de blancos.

[34] Martínez-Alier, Marriage, Class and Colour, 66.

[35] Ortiz, Los negros esclavos reports white gender ratios of 1.44, 1.49, and 1.24 for 1867, 1877, and 1887, respectively. These figures also omit the presence of Spanish soldiers.

[36] Reconocimientos, Leg. 34 exp. 54, 1874.

[37] Reconocimientos, Leg. 34 exp. 54, 1874.

[38] Scott, Slave Emancipation.

[39] Reconocimientos, Leg. 52 exp. 61, 1878.

[40] Reconocimientos, Leg. 51 exp. 17, 1878.

[41] Reconocimientos, Leg. 58 exp. 20, 1880.

[42] Martinez-Alier, Marriage, Class and Colour, 17-18. From this current data set, there is some indication that the men filing these petitions preferred to shift women into the parda category. Such a relabelling occurred with Juana Fundora. Although her own baptismal certificate recorded her parents as a Congolese man and a black Creole woman, her partner's paternity claim listed her as parda, Leg. 90 exp. 38, 1887.

[43] An indication of colour was absent in one petition. The mother was only listed as enslaved.

[44] Of the nineteenth-century censuses, only the 1827 and 1846 distinguish enslaved people by colour and gender. In 1846, there were 84,641 morena slaves and only 3,041 pardas. See Cuba, Cuadro estadistico de la siempre fiel isla de Cuba correspondiente al año 1846, 50. It is likely that the proportion of pardas increased for the rest of the slaveholding period but would remain much less than that of the black female population.

[45] A classic example of the white popular image of the mulatta is the nineteenth-century Cuban novel Cecila Valdes o la loma de Angel by Cirilo Villaverde. Also see Kutzinski, Sugar's Secrets.

[46] Reconocimientos, Leg. 90 exp. 13, 1887.

[47] It is interesting to note that the woman involved in this case in 1877 had a child by another white father, while she remained enslaved. That father registered paternity for the child in 1887 , and the couple married in 1890 . The marriage was recorded in the marriage registry for whites. Reconocimientos, Leg. 89 exp. 77, 1887 and Leg. 100 exp. 73, 1890.

[48] Scott, Slave Emancipation, 12-13.

[49] See Scott, Degrees of Freedom, 25-26 for discussion of social heterogeneity of late colonial Cuba. 
[50] Cowling, 'Negotiating Freedom' 383-384.

[51] Reconocimientos, Leg. 90 exp. 38, 1887.

[52] García Rodríguez, La esclavitud desde la esclavitud applies to Cuba an awareness of the social negotiations between slaves and owners originally demonstrated in Genovese's Roll, Jordan, Roll. Beckles, Centering Women reviews the types of intimate exchange involving slave women and white men in the late eighteenth-century British West Indies. For one such lasting relationship in Spanish Florida, see Schafer, Anna Madgigine Jai Kingsley.

[53] The peak female slave population was reached in 1841 with 155,245 women and girls. By 1862 it had decline by only $2.3 \%$, or 3,414 , which was dramatically less than the $22.2 \%$ seen for male slaves over the same period. Between 1867 and 1877 the number of female slaves decreased dramatically, by $38 \%$, from 141,203 to 86,902, see Ortiz, Los negros esclavos, 22 . Given that by 1877 the 1870 Moret Law had freed only 37,603 persons of both sexes, the rationale behind the female decrease remains obscured, see Scott, Slave Emancipation, 72. This study uses 1878 as the year in which adult women in their reproductive years were most impacted by state abolition policies. Before that time, enslaved people benefited from more individualised liberation strategies.

[54] Barras y Prado, La Habana a mediados del siglo XIX, 114-115, quoted in Mena, 'Stretching the Limits of Gendered Spaces', 96.

[55] This story is told in Barcia, La otra familia, 51-53, along with the publication of the full carta de libertad (letter of freedom) for both María Quirina and her son Rafael, 181-183.

[56] Determination of a woman's transition to freedom is linked to her status change across the baptismal certificates of her children. Therefore, with women for whom only one child received paternal recognition, it is generally not possible to determine whether she made the transition out of slavery before the 1880 start of the final patroncinato apprenticeship period.

[57] Reconocimientos, Leg. 31 exp. 2, 1873.

[58] Martínez-Fernández, Fighting Slavery in the Caribbean, 132.

[59] Proctor III, 'Gender and the Manumission of Slaves in New Spain' demonstrates that caution is needed in attributing female manumission to sexual relations. Studies of nineteenth-century Cuban manumission rates vary widely in their results. Duharte Jiménez, Seis ensayos de interpretación histórica indicates that only $1 \%$ of the Cuban slave population gained coartado status (or had begun to purchase their freedom) before 1840 and the practice declined after that time. By contrast, Begard et al., The Cuban Slave Market, 145 reveals that for every slave sale, there was one purchase of freedom.

[60] AES, libro 54 de bautismos de pardos y morenos, entry 387, 1867.

[61] AES, libro 55 de bautismos de pardos y morenos, entries 497, 650, 651, and 652.

[62] Reconocimientos, Leg. 66 exp. 90, 1881.

[63] Reconocimientos, Leg. 61 exp. 87, 1881.

[64] Reconocimientos, Leg. 46, exp. 56, 1877. By the middle of the nineteenth century, 25 pesos was the customary amount paid to free an unborn child; see de la Fuente, 'Slaves and the Creation of Legal Rights in Cuba'.

[65] The literature on this theme is extremely rich. A brief review appears in Dorsey, 'Women without History.

[66] Reconocimientos, Leg. 83 exp. 70, 1878.

[67] Reconocimientos, Leg. 43 exp. 26, 1876.

[68] Reconocimientos, Leg. 88 exp. 25, 1886.

[69] Reconocimientos, Leg. 89 exp. 77, 1887 and Reconocimientos, Leg. 102 exp. 5, 1890.

[70] Reconocimientos, Leg. 114 exp. 68, 1893.

[71] Recopilación de las leyes de los reinos de las Indias, libro 7, titutlo V, ley VI.

[72] Reconocimientos, Leg. 102 exp. 5, 1890.

[73] An allusion to the secrecy surrounding children born of white fathers and enslaved mothers is also found in Reconocimiento, Leg. 2 exp. 6, 1851. Here, a priest expresses his suspicion that a mother is a slave, instead of white, as the father had claimed. 
[74] Reconocimientos, Leg. 6 exp. 43, 1863.

[75] Lewis and Onuf, 'Introduction', 7.

\section{References}

Aimes, Hurbert. A History of Slavery in Cuba, 1511-1868. New York: Octagon Books, 1967; originally G.P. Putnam's Sons, 1907.

Arrom, Sylvia. "Marriage Patterns in Mexico City, 1811." Journal of Family History 3, no. 4 (1978): 376-391.

Baptist, Edward. “'Cuffy', 'Fancy Maids', and 'One-Eyed Men': Rape, Commodification, and the Domestic Slave Trade in the United States." American Historical Review (2001), 1619-1650.

Barcia, María del Carmen. La otra familia: parientes, redes y descendencia de los esclavos en Cuba. Havana: Casa de las Américas; 2003.

Barras y Prado, Antonio de las. La Habana a mediados del siglo xix: Memorias de Antonio de las Barras y Prado. Madrid: Imprenta de la Ciudad Lineal, 1925.

Beckles, Hilary. Centering Women: Gender Discourse in Caribbean Slave Society. Kingston, Jamaica: Ian Randle Publishers, 1998.

Begard, Laird, Fe Iglesias García, and María del Carmen Barcia. The Cuban Slave Market, 1790-1880. Cambridge: Cambridge University Press, 1995.

Burns, Kathryn. "Gender and the Politics of Mestizaje." Hispanic American Historical Review 78, no. 1 (1998): 5-44.

Calvo, Thomas. "Concubinato y mestizaje en el medio urbano: El caso de Guadalajara en el siglo XVIII." Revista de Indias 44, no. 173 (1984): 203-212.

Castellanos, Jorge, and Isabel Castellanos. Cultura Afrocubana. Vol. 2. El negro en Cuba, 1845-1859. Miami: Ediciones Universal, 1990.

Chandler, David L. "Family Bonds and the Bondsman: The Slave Family in Colonial Colombia." Latin American Research Review 16, no. 2 (1981): 107-131.

Cope, Douglas. The Limits of Racial Domination: Plebeian Society in Colonial Mexico City, 16601720. Madison: University of Wisconsin Press, 1994.

Cowling, Camillia. "Negotiating Freedom: Women of Colour and the Transition to Free Labour in Cuba, 1870-1886." Slavery and Abolition 26, no. 3 (2005): 377-391.

Craton, Michael. Searching for the Invisible Man: Slaves and Plantation Life in Jamaica. Cambridge: Harvard University Press, 1978.

Cuadrado Melo, Manuel. Obispado de la Habana, su historia a traves de los siglos. Havana: np, 1970.

Cuba, Comisíon de estadística. Cuadro estadistico de la siempre fiel isla de Cuba correspondiente al año 1846. Havana: Imprenta del Gobierna y Capitania General por S.M, 1847.

Dabney, Virginius. The Jefferson Scandals: A Rebuttal. New York: Dodd, Mead, 1981.

Davis, Angela. "Reflections on the Black Woman's Role in the Community of Slaves." Black Scholar 3 (Dec. 1971): 3-15.

. Women, Race, and Class. New York: Random House Vintage, 1983.

Degler, Carl. Neither Black Nor White: Slavery and Race Relations in Brazil and the United States. New York: Macmillan, 1971.

Duharte Jiménez, Rafael. Seis ensayos de interpretación histórica. Editorial Oriente, Santiago de Cuba, 1983.

de la Fuente, Alejandro. "Matrimonios de esclavos en la Habana, 1585-1645." Archivo IberoAmericano 16, no. 4 (1990): 507-528.

. "Race and Inequality in Cuba, 1899-1981." Journal of Contemporary History 30 (1995): $131-167$.

. "Slave Law and Claims-Making." Law and History Review 22, no. 2 (2004): 339-370.

- "Slaves and the Creation of Legal Rights in Cuba: Coartación and Papel." Hispanic American Historical Review 87, no. 4 (2007): 659-692. 
Dorsey, Joseph. "Women without History: Slavery and the International Politics of Partus Sequitur Ventrem in the Spanish Caribbean." Journal of Caribbean History 28, no. 2 (1994): 165-207.

Freyre, Gilberto. The Masters and the Slaves: A Study in the Development of Brazilian Civilization, trans., 2nd edn. Berkeley: University of California Press, 1986; original Casa-Grande \& Senzala, 1933.

Gacto Fernández, Enrique. La filación no Legítima en el Derecho Histórico Español. Sevilla: Universidad de Sevilla, 1969.

García Rodríguez, Gloria. La esclavitud desde la esclavitud: La visión de los Siervos. Mexico: Centro de Investigación Científica 'Ing. Jorge L. Tamayo, 1996.

Genovese, Eugene. Roll Jordan, Roll: The World the Slaves Made. New York: Random House Vintage Books, 1976.

Giddings, Paula. Where and When I Enter: The Impact of Black Women on Race and Sex in America. New York: William Morrow, 1984.

Gordon-Reed, Annette. The Hemingses of Monticello: An American Family. New York: W.W. Norton, 2008.

- Thomas Jefferson and Sally Hemings: An American Controversy. Charlottesville: University Press of Virginia, 1997.

Gutman, Herbert G. The Black Family in Slavery and Freedom, 1750-1925. New York: Pantheon, 1976.

Higman, Barry. Slave Populations of the British Caribbean, 1807-1834. Baltimore: The Johns Hopkins University Press, 1984.

Humbolt, Alexander von, Ensayo político sobre la Isla de Cuba. trans. José López de Bustamante, nueva edición. Paris: Lecointe y Lassere, 1840.

Karash, Mary. Slave Life in Rio de Janeiro, 1808-1850. Princeton: Princeton University Press, 1987.

Klein, Herbert S. Slavery in the Americas: Comparative Study of Virginia and Cuba. Chicago: University of Chicago Press, 1967.

Kutzinski, Vera. Sugar's Secrets: Race and the Erotics of Cuban Nationalism. Charlottesville: University Press of Virginia, 1993.

Kuznesof, Elizabeth A. "Who were the Families of 'Natural' Children of Nineteenth-Century Rio de Janeiro." History of the Family 2, no. 2 (1997): 171-182.

Lewin, Linda. "Natural and Spurious Children in Brazilian Inheritance Law from Colony to Empire: A Methodological Essay." The Americas 48, no. 3 (1992): 351-396.

- Surprise Heirs I, Illegitimacy, Patrimonial Rights, and Legal Nationalism in Luso-Brazilian Inheritance, 1750-1821. Stanford: Stanford University Press, 2003.

Lewis, Jan, and Peter Onuf, eds. Sally Hemings \& Thomas Jefferson: History, Memory, and Civic Culture. Charlottesville: University Press of Virginia, 1999.

Malone, Ann. Sweet Chariot: Slave Family and Household Structure in Nineteenth-Century Louisiana. Chapel Hill: The University of North Carolina Press, 1992.

Martínez-Alier, Verena. Marriage, Class and Colour in Nineteenth-Century Cuba: A Study of Racial Attitudes and Sexual Values in a Slave Society, 2nd edn. Ann Arbor: University of Michigan Press, 1989, originally 1974.

Martínez-Fernández, Luis. Fighting Slavery in the Caribbean: The Life and Times of a British Family in Nineteenth-Century Havana. Armonk, NY: M.E. Sharpe Publishers, 1998.

McClintock, Anne. Imperial Leather: Race, Gender, and Sexuality in the Colonial Contest. New York: Routledge, 1995.

Mena, Luz. "Stretching the Limits of Gendered Spaces: Black and Mulatto Women in 1830s Havana." Cuban Studies 36 (2005): 87-104.

Menke, John G. Mulattoes and Race Mixture: American Attitudes and Images, 1865-1918. Ann Arbor: University of Michigan Press, 1979.

Mörner, Magnus. Race Mixture in the History of Latin America. Boston: Little, Brown, 1967. 
Morrison, Karen Y. "Creating an Alternative Kinship: Slavery, Freedom, and Nineteenth-Century Afro-Cuban Hijos Naturales." Journal of Social History (2007), 55-80.

Murray, David. Odious Commerce: Britain, Spain and the Abolition of the Cuban Slave Trade. Cambridge: Cambridge University Press, 1980.

Nash, Gary. "The Hidden History of Mestizo America." In Sex, Love, Race: Crossing Boundaries in North American History, edited by M. Hodes. New York: New York University Press, 1999.

Needell, Jeffrey. "Identity, Race, Gender, and Modernity in the Origins of Gilberto Freyre's Oeuvre." The American Historical Review 100, 1 (February 1995): 51-77.

Ortiz, Fernando. Los negros esclavos. Havana: Revista Bimestre Cubana, 1916.

Perera Diaz, Aisnara and María de los Angeles Fuentes Meriño. Esclavitud, Familia, y Parroquia en Cuba: Otra Mirada desde la Microhistoria. Santiago de Cuba: Editorial Oriente, 2006.

Petley, Christopher. "'Legitimacy' and Social Boundaries: Free People of Colour and the Social Order in Jamaican Slave Society." Social History 30, no. 4 (2005): 481-498.

Portuondo de Castro, José. La Filación. Havana: np, 1947.

Potthast-Jutkeit, Barbara. "The Creation of the 'Mestizo Family Model': The Example of Paraguay." History of the Family 2, no. 2 (1997): 123-140.

Proctor III, Frank. "Gender and the Manumission of Slaves in New Spain." Hispanic American Historical Review 86, 2 (May 2006): 309-336.

- Recopilación de las leyes de los reinos de las Indias. Madrid: Boix Editor, 1841, original 1680.

Redfield, Levi. A Succinct Account of Some Memorable Events and Remarkable Occurrences in the Life of Levi Redfield, Late of Connecticut, now residing in Brattleboro' Ver. Written by Himself. Brattelborough, Vt.: B. Smead, 1798.

Rout, Leslie. The African Experience in Spanish America, 1502 to the Present Day. New York: Cambridge University Press, 1976.

Saco, Antonio. Historia de la esclavitud de la raza africana en el Nuevo Mundo y en especial en los paises américo-hispanos. 4 vols. Havana: Cultural, 1938, originally 1875.

Schafer, Daniel. Anna Madgigine Jai Kingsley: African Princess, Florida Slave, Plantation Slaveowner. Gainesville: University Press of Florida, 2003.

Scott, Rebecca Jarvis. Degrees of Freedom, Louisiana and Cuba after Slavery. Cambridge: Harvard University Press, 2005.

Scott, Rebecca Jarvis. Slave Emancipation in Cuba: The Transition to Free Labor, 1860-1899. Princeton: Princeton University Press, 1985.

Skidmore, Thomas. "Race and Class in Brazil: Historical Perspectives." In Race, Class and Power in Brazil, edited by P. Fontaine. Los Angeles: CAAS, 1985.

Slenes, Robert. "Black Homes, White Homilies: Perceptions of the Slave Family and of Slave Women in Nineteenth-Century Brazil." In More Than Chattel: Black Women and Slavery in the Americas, edited by D.B. Gaspar and D.C. Hine. Bloomington: University of Indiana Press, 1996. - Na Senzala, Uma Flora: Esperanças e Recordações na Formação da Família Escrava. Rio de Janeiro: Nova Fronteira, 1999.

Smith, Raymond T. The Negro Family in British Guiana: Family Structure and Social Status in the Villages. London: Routledge \& Kegan Paul, 1956.

Stevenson, Brenda E. Life in Black and White: Family and Community in the Slave South. New York: Oxford University Press, 1996.

Stoler, Ann. Carnal Knowledge and Imperial Power. Berkeley: University of California Press, 2002.

Tannenbaum, Frank. Slave and Citizen: The Negro in the Americas. 1946; Boston: Beacon Press, 1992.

The Thomas Jefferson Foundation, "Thomas Jefferson and Sally Hemings: A Brief Account" (accessed 15 November 2005). Available online from http://www.monticello.org/ plantation/hemingscontro/hemings-jefferson_contro.html.

The Thomas Jefferson Heritage Society, Jefferson-Hemings Scholars Commission, "Report on the Jefferson-Hemings Matter," 2 April 2001, (accessed 15 November 2005). Available at http:// www.tjheritage.org/scholars.html. 
Twinam, Ann. Public Lives, Private Secrets: Gender, Honor, Sexuality, and Illegitimacy in Colonial Spanish America. Stanford: Stanford University Press, 1999.

Villaverde, Cirilio. Cecilia Valdés. Habana: Editorial Letras Cubanas, 1979 [orig. 1879].

White, Deborah Gray. Ar'n't I a woman?: Female Slaves in the Plantation South. rev edn. New York: W.W. Norton, 1999.

Williamson, Joel. New People: Miscegenation and Mulattoes in the United States. New York: Free Press, 1980.

Wood, Charles H., and Lovell. "Skin Color, Racial Identity, and Life Chances in Brazil." Latin American Perspectives 25, no. 3 (May 1998): 90-109.

Woodson, Byron. A President in the Family: Thomas Jefferson, Sally Hemings, and Thomas Woodson. Westport: Praeger, 2001. 